\title{
NON-PERFORMING LOANS, CAPITAL ADEQUACY, LOAN LOSS PROVISION, AND BANK PROFITABILITY: A CASE OF LICENSED GHANAIAN BANKS
}

\begin{tabular}{|c|c|}
\hline${ }^{1}$ Shuibin Gu & $\begin{array}{l}{ }^{1,} \text { Jiangsu University, School of Finance and Economics, } \\
\text { China }\end{array}$ \\
\hline${ }^{2}$ Ofori Charles* & $\begin{array}{c}{ }^{2,} \text { Jiangsu University, School of Finance and Economics, } \\
\text { China }\end{array}$ \\
\hline${ }^{3}$ Takyi Kwabena Nsiah & $\begin{array}{c}{ }^{3} \text { Jiangsu University, School of Finance and Economics, } \\
\text { China }\end{array}$ \\
\hline${ }^{4}$ Eric Dwomoh & ${ }^{4}$ Nestlé Ghana Limited, Accra, Ghana \\
\hline${ }^{5}$ Weveh-Wilson Benjamin & $\begin{array}{c}{ }^{5} \text { SD Dombo University of Business and Integrated } \\
\text { Development Studies, Ghana }\end{array}$ \\
\hline
\end{tabular}

\section{ABSTRACT}

Article DOI URL: https://doi.org/10.36713/epra5421

This article explored the affiliation between a non-performing loan, capital adequacy ratio, loan loss provision, and bank profitability. The study was conducted on the licensed commercial banks in Ghana for the era 2014-2019. The two-step system generalized method of moments estimator was utilized to test the hypothesis developed for the study. The independent study variables altogether demonstrated a negative and immaterial association with the bank's profitability as proxied by ROA. A robustness test was conducted utilizing the Three-Stage Least-Squares Regression (3SLS); the outcome was analogous to that of the Two-Step System Generalized Method of Moments estimator. The study suggests that the Central Bank fortifies the capital requirement and keenly monitors banks' risk-taking conduct and banks undertaking due diligence procedures to moderate the shock of non-performing loans and loan loss provision in other to augment the profitability of universal banks.

KEYWORDS: Non-Performing Loans, Capital Adequacy, Loan Loss Provision, Bank Profitability, GMM JEL Codes: E58, G21, G32 


\subsection{INTRODUCTION}

The function of commercial banks is significant in the fiscal growth of every nation-state across the world. Banks set up an atmosphere intended for individuals as well as businesses to access credit services. Companies are liable to default on their credits because of moral hazards and adverse selection, imping on the bank's profitability (Basel, 2001). Ghana's banking structure has gone through an enormous deal of distress in the past five years as the country has seen many banks collapse.along with others either merged or consolidated. Nonperforming loans, inadequate capital amid others were the fundamental cause of the distress.

Banks grant credit facilities to its client based on the risk data at their disposal. In a case whereby a party to the contract, herein, the client, is privy to the risk associated with the venture (Edwards and Turnbull, 1994 and Krugman, 2009). Asymmetric information gives rise to moral hazard and adverse selection. Banks might not hold complete knowledge of the kind of venture clients will embark on at the outset. Yet again, loans are insured in recent times, and as such, the debtor has an enticement to default. Subsequently, out of the frequent clients who opt for loan facilities from banks, banks are likely to default in choosing a suitable client who can repay the loan as per the contractual agreement.

The signaling theory states that for banks to build their dependence and legacy, demand for collateral from clients to safeguard the credit in case of non-payment as cited by (Okoye and Eze (2013), Abiola and Ikhu-Omoregbe (2017), Olugboyega (2018)). Based on the bank's risk evaluation, a client who seeks for the facility to commence a riskier enterprise supports the loan request with a levelheaded amount of security to preserve the loan.

Amongst the researchers who considered the determinants of bank profitability, ascribe it to numerous variables. The literary world has surveyed the issue and argument on top of the topic capital adequacy for decades on the capital banks ought to preserve to smooth the progress of lending, expansion, payment of short- and long-term debts, and other extreme issues those banks countenance.

In Ghana, Antwi (2019) investigated Capital Adequacy, Cost Income Ratio, and the profitability of listed banks in Ghana 'posited that capital adequacy negatively influences the bank's profitability. Similarly, Sanyaolu (2019) utilized the fixed effect regression estimator on Nigerian banks and established a considerable affirmative linkage amid CAR and bank profitability.

Previous studies notion non-performing loans as a vital determinant of the bank's profitability. In Sri Lanka, Suganya and Kengatharan (2018) explored the bond connecting banks' specific variables and home registered banks' financial profitability. The discoveries demonstrated the adverse effects of NPL on financial profitability.
Again, Kodithuwakku (2015) recognized a negative affiliation between NPL and bank profitability in Sri Lanka for 2009 up to 2013. There exist conflicting conclusions in the studies of (Gizaw and Selvaraj, 2015; Nasserinia, Ariff, and Fah-Fan, 2014; Boahene et al., 2012; Naceur and Omran, 2011; Weersainghe and Perera, 2013) whose study projects a positive link between NPL and banks profitability.

Loan loss provision has developed into a concern in the study of the bank's profitability. The results (Ogboi and Unuafe, 2013; Zulfikar, 2019 and Tariq et al., 2014) bring into being a positive connection between loan loss provision and bank profitability. For the period $2007-2016$, Annor and Obeng (2017) explored enlisted banks on the Ghana Stock Exchange on credit risk management impacts on profitability. The article established a negative tie connecting loan loss provision and profitability. This investigation was coherent with the works of literature by Islam (2018) and Kolapo (2012).

On the input to existing literature, this study looks at the connection among NPL, CAR, LLP, and bank profitability utilizing the Two-Step System Generalised Method of Moments as newness in the methodology. Earlier studies centered on either the link that exists between one or two of the above factors. Second, the article varies from the previous studies conducted in the Ghanaian setting by including more banks than a small number of listed on the Ghana Stock Exchange (GSE).

\subsection{LITERATURE REVIEW 2.1.1 Non-Performing Loans and Bank Profitability}

Non-performing loans refer to assets whose installments are past due for at least 90 days (CBK, 2013). Asif (2019), via a panel regression, found a malicious link between NPL and the profitability of banks in Indian amid the period of 2005-2018. Suganya and Kengatharan (2018) considered the Specific Factors and Financial Profitability of Domestic Licensed Commercial Banks in Sri Lanka. The study established that NPL was negatively correlated to bank profitability.

Kodithuwakku (2015) examined the nexus between credit risk management and the profitability of eight banks in Sri Lanka from 2009-2013. The outcome of the study exhibited that NPL and ROA are negatively connected. Kurawa and Garba (2014) studied the consequence of credit risk management on banks' profitability in Nigerian for the interval 2002 to 2011. The study utilized random GLS regression and concluded that NPL has a negative association with ROA. Annor and Obeng (2017) found NPL to be significantly and negatively connected in listed banks in Ghana from 2007 to 2016. An escalating NPL influences the bank's capacity to offer credit facilities, consequently affecting its profitability. Banks must ensure substantial risk management strategies and satisfactory due diligence before granting credits. 
(Gizaw and Selvaraj, 2015; Nasserinia et al., 2014). Based on the above, the study embraced the null hypothesis that;

$H_{1}:$ NPLR has a negative affiliation with bank profitability in Ghana.

\subsubsection{Capital Adequacy and Bank Profitability}

Ozili (2015) analyzing the components that influence profitability and Basel capital regulation on Nigerian banks. The studies bring into being an affirmative and significant association between CAR and ROA and net interest margin (NIM) as proxies for bank profitability. Suganya and Kengatharan (2018) conducted a study on the Specific Factors and Financial Profitability of Domestic Licensed Commercial Banks in Sri Lanka. The study found that capital adequacy is positively linked with bank profitability. Rahman (2018) explored the nexus of capital regulation, risk, and profitability of banks in Bangladesh; the outcome showed a positive linkage between bank capital and profitability. Majumder and Li (2018) found a significantly positive correlation between bank capital and profitability.

Sanyaolu (2019), utilizing the fixed effects regression on the Determinants of Profitability of Nigerian Deposit Money Banks from 2008-2017, asserted that CAR is significantly positive with return on assets (ROA). Rahman et al. (2015) conducted a study in Bangladesh using a sample size of twentyfive banks. Employing the GMM estimator found a significant positive relation between CAR and bank profitability as proxied by ROA and ROE. Çekrezi (2015) examined the factors affecting the profitability of commercial banks in Albania using a sample size of sixteen banks from 2010-2013, found CAR to be complimentary with ROA. Kurawa and Garba (2014) assert that CAR has an immaterially positive link with ROA. Olugboyega (2018) studied the effects of credit risk and bank profitability in Nigeria using the random effect GLS regression technique; the study found a significantly positive relationship between CAR and bank profitability. Hence the development of the hypothesis below;

\section{$H_{2}$ : CAR has a positive affiliation with banks' profitability in Ghana}

\subsubsection{Loan Loss Provision and Banks Profitability}

According to the CBK's prudential guideline, banks should make a $20 \%$ provision for substandard loans and $100 \%$ provision for loans in doubtful and loss categories. Previous studies (Ogboi and Unuafe, 2013; Tariq et al., 2014) found a positive correlation between loan loss provision and bank profitability. The study employed the panel data regression technique and established that LLP has a significant and positive ROA correction. Zulfikar (2019) examined the relationship between LLP and bank profitability in Indonesia. Employing the Partial Least Squares-Structural Equation modeling on thirteen banks. The result depicted a positive link between LLP and bank profitability. Based on the above, we hypothesize that;

$H_{3}$ : LLP has a positive affiliation with the profitability of banks in Ghana.

\subsection{METHODOLOGY}

\subsubsection{Data Source and Study Design}

By experimenting, the proposed hypotheses would be negated or upheld quantitatively. Annual financial reports of the twenty-three banks licensed by the Bank of Ghana were utilized for this study. The study collected data from 2014 up to 2019, employing STATA version 15 in analyzing the data. The sample dimension offsets criticism that previous studies in Ghana notably incurred.

Table 1: Definition of study variables

\begin{tabular}{ccc}
\hline Dependent & Measurement & Source \\
\hline ROA & Net Profit for the year /Net asset & Annual report \\
\hline $\begin{array}{c}\text { Independent } \\
\text { (NPLR) }\end{array}$ & Non-performing loans / Total loans & Annual report \\
\hline Capital Adequacy Ratio (CAR) & Total capital/Total Assets & Annual report \\
\hline Loss Loan Provision Ratio (LLPR) & Loss Provisions / Total Loans & Annual report \\
\hline & Control & \\
\hline Bank size (S.Z.) & Log of the bank's total assets & Annual report \\
\hline Liquidity (LIQ) & Loans and Advance / Deposit ratio. & Annual report \\
\hline Interest Rate (INT) & Annual interest rate & World Development \\
& & Indicators \\
\hline
\end{tabular}

Source: Authors' computation

\subsubsection{Model}

To aid in fully understanding the correlation between the dependent and independent factors. The study proposes the econometric model below: 
$R O A_{i t}=\alpha+\beta 1 N P L R_{i t}+\beta 2 C A R_{i t}+\beta 3 L L P R_{i t}+\beta 3 C T L_{i t}+e_{i t}$

Where ROA as return on asset (a proxy for bank profitability), NPLR as non-performing loan ratio, LLPR as loan loss provision ratio., CTL (size and liquidity), $\alpha$ is the constant, and e is the error term which should not be correlated with the regressors, $i(i=1,2,3 \ldots N)$ represents the studied banks, and $t(1,2,3 \ldots T)$ denote the time frame. All the data analysis was conducted using Stata version 15.0 software package.

\subsubsection{Method}

To ascertain the affiliation among banks' profitability, non-performing loans, capital adequacy ratio, and loan loss provision ratio. The two-step dynamic panel-data estimation model was adopted for the study, as stated below.

$$
\Delta Y i t=\alpha+\delta Y_{i, t-1}+\beta_{1} X i t+y t+\varepsilon_{t}
$$

Where $\Delta$ Yit represents the change in banks' profitability as proxied by ROA, i represents a bank and $t$ as a given time point. The lag of banks was defined as (i, t-1). The explanatory variables, NPLR, CAR, LLPR, SIZE, LIQUID, and INT at a given time, were represented as Xit. $\beta$ represents the coefficient of the independent variables. The time fixed effects are evenly distributed across all the banks modeled as $\gamma t$. The disturbance is characterized by $\varepsilon$ t. Coefficient $\delta$ measures the relational condition upon the explanatory variable. The equation below was derived from equation (2).

$$
\Delta R O A=\alpha+\beta_{0} R O A_{i, t-1}+\beta_{1} N P L R_{i t}+\beta_{2} C A R_{i t}+\beta_{3} L L P R_{i t}+\beta_{4} S Z_{i t}+{ }_{5} L I Q_{i t}+\beta_{5} I N T_{i t}+\gamma t+\varepsilon t .
$$

ROA denotes return on assets, NPLR represents Non-performing loans, CAR as Capital adequacy ratio, LLPR as Loan loss provision ratio, S.Z. as the log of a banks' assets, and LIQ the liquidity of banks, and INT as the interest rate. $\varepsilon t$ represents individual disturbance. The study theory evaluates the affiliation between credit risk and banks' profitability, and therefore the estimated coefficient supports the model above.

The ordinary least square (OLS) method was not employed in estimating Eq. (2) due to its bias, failure to cater to bank-specific effects, and inability to resolve endogeneity issues of the study regressors. Unlike the OLS, the Generalised Method of Moments developed by (Arellano and Bond (1991), Arellano and Bover (1995)) and the fully modified version by Blundell and Bond (1998) is an appropriate estimator as it offsets all the limitations of OLS.

According to (Arellano and Bover (1995), Blundell and Bond (1998)), the system generalized method of moments is best in regulating issues of weak instruments. The two-step system GMM estimator is developed for a small number of " $\mathrm{T}$ " and large "N," which may have an inherent fixed and separate effects. As stated by Reed (2015), the appropriateness of the lagged values of the explanatory variables precedes the absence of autocorrelation and a weak exogeneity of the study disturbance. The diagnostic tests accompanying the GMM estimator are the Hansen J- stats test to check whether there exists a link between the instruments of the study and its residuals and the Sargan test, which exhibits the validity of the instrument employed. Lastly, the Arellano-Bond test which does establish the first and second-order autocorrelation link.

\subsection{RESULTS AND DISCUSSION} 4.1.1 Descriptive Statistics

This section includes a concise description of the research variables aspects of their mean, standard deviations, minimum and maximum values. The results indicated a ROA with mean and standard deviation values of 0.0321 and 0.018 , respectively. Similarly, NPLR, CAR, and LLPR produce a mean and standard deviation figures of $0.416,0.304$, and $0.142 ; 0.134,0.187$, and 0.102 . S.Z. Ranges from 5.294 to 9.445 . The table contains the interpretation of the other studied variables.

Table 2: Descriptive Statistics

\begin{tabular}{cccccc}
\hline Variable & Obs & Mean & Std. Dev & Min & Max \\
\hline ROA & 138 & 0.032 & 0.019 & -0.040 & 0.070 \\
NPLR & 138 & 0.416 & 0.134 & 0.092 & 0.755 \\
CAR & 138 & 0.304 & 0.188 & 0.041 & 0.863 \\
LLPR & 138 & 0.142 & 0.102 & 0.001 & 0.456 \\
SZ & 138 & 7.102 & 1.155 & 5.294 & 9.445 \\
LIQ & 138 & 1.164 & 0.289 & 0.109 & 2.266 \\
INT & 138 & 20.739 & 3.757 & 16.014 & 26.125 \\
\hline
\end{tabular}

Source: Authors' computation 


\subsubsection{Pearson product-moment correlation}

This part of the research presents the association between the dependent and independent factors and the controls. There is an adversely insignificant affiliation between ROA and NPLR, indicating that when banks cannot collect credits granted to their customers, their profitability is adversely affected. Also, CAR had a positive and significant link with the banks' return on assets. The above implies that the capital adequacy ratio significantly improves profitability.

However, the loan loss provision ratio had a negative association with ROA. The implication of this coefficient indicates that banks make provision of loans at $33.76 \%$ of loans granted out to cover bad debts. The size of the firms exhibited a negative and significant relationship with ROA. This affiliation shows that small firms grant fewer credits than more significant firms with large capital base. On the part of liquidity, there was a positive and insignificant connection. The above indicates that banks keep enough cash and cash equivalent to meet their shortterm liabilities and invest in other market securities to improve their profitability. The insignificant association's economic implication suggests that liquidity indirectly affects the profitability of the sampled banks as proxied by ROA.

Table 3. Pearson Product-Moment Correlation

\begin{tabular}{|c|c|c|c|c|c|c|c|}
\hline & ROA & NPLR & CAR & LLP & SIZE & LIQUID & INT \\
\hline ROA & 1.000 & & & & & & \\
\hline \multirow[t]{2}{*}{ NPLR } & -0.254 & 1.000 & & & & & \\
\hline & $0.003^{*}$ & & & & & & \\
\hline \multirow[t]{2}{*}{ CAR } & 0.267 & -0.511 & 1.000 & & & & \\
\hline & $0.002^{*}$ & $0.0000^{*}$ & & & & & \\
\hline \multirow[t]{2}{*}{ LLP } & -0.334 & 0.547 & -0.400 & 1.000 & & & \\
\hline & $0.000^{*}$ & $0.000^{*}$ & $0.000^{*}$ & & & & \\
\hline \multirow[t]{2}{*}{ SIZE } & -0.373 & 0.459 & -0.207 & 0.294 & 1.000 & & \\
\hline & $0.000^{*}$ & $0.000 *$ & $0.015^{*}$ & $0.005^{*}$ & & & \\
\hline \multirow[t]{2}{*}{ LIQUID } & 0.008 & 0.337 & -0.210 & 0.187 & 0.488 & 1.000 & \\
\hline & 0.924 & $0.001^{*}$ & $0.013^{*}$ & $0.028 *$ & 0.000 & & \\
\hline \multirow[t]{2}{*}{ INT } & 0.117 & 0.081 & 0.066 & 0.035 & -0.017 & -0.134 & 1.000 \\
\hline & 0.174 & 0.347 & 0.445 & 0.681 & 0.846 & 0.117 & \\
\hline
\end{tabular}

Note: *denotes significance level of $10 \%$

\subsubsection{The Two-Step System General Method of Moments Estimation}

The article adopted the two-step system general method of moments estimator to evaluate the influence of non-performing loans, capital adequacy ratio and loan loss provision on Ghanaian licensed banks' profitability. The GMM results uncovered that NPLR had a negative and insignificant connection with the profitability with a coefficient value of .05107 and $\mathrm{p}>0.1$ (0.828). This figure implies that a unit increase in NPLR leads to a -.0510724 reduction in return on assets.
Source: Authors' computation

Although CAR negatively affected banks' profitability in the study, the effect was statistically insignificant. A percentage decrease in CAR resulted in a percentage decrease in ROA. Again, the investigation on LLPR had an insignificantly favorable implication on Ghana's commercial banks' profitability. On the test of size, the results show a negative and weak significant connection with the sampled banks' ROA. Liquidity ratio, which measures the ease at which banks' meet its short-term liabilities, had an insignificantly favorable affiliation with the banks' profitability.

Table 4. The Two-Step System General Method of Moments Estimation

\begin{tabular}{ccccccc}
\hline & Coef & Std. Err & Tstat & P $>|\mathbf{t}|$ & [95\% Conf.Interval \\
\hline ROA L1 & & & & & & 0.626 \\
NPLR & -0.051 & 0.224 & -0.23 & 0.828 & -0.524 & 0.229 \\
CAR & -0.002 & 0.089 & -0.02 & 0.984 & -0.233 & 0.244 \\
LLP & -0.283 & 0.205 & -1.38 & 0.226 & -0.809 & 0.032 \\
SIZE & -0.003 & 0.014 & -0.21 & 0.846 & -0.038 & 0.081 \\
LIQUID & 0.023 & 0.022 & 0.99 & 0.366 & -0.036 & 0.004 \\
INT & 0.002 & 0.000 & 3.26 & 0.023 & 0.000 & \\
\hline
\end{tabular}

Source: Authors' computation 
Table 5. Diagnostic Estimations

\begin{tabular}{|c|c|c|c|}
\hline Test & Statistics & \multicolumn{2}{|c|}{ Prob. } \\
\hline $\operatorname{AR}(1)$ & $z=-1.69$ & \multicolumn{2}{|c|}{0.090} \\
\hline AR (2) & $\mathrm{z}=0.01$ & \multicolumn{2}{|c|}{0.995} \\
\hline Sargan test & $\operatorname{chi} 2(8)=112.25$ & \multicolumn{2}{|c|}{0.000} \\
\hline Hansen test & $\operatorname{chi} 2(8)=0.00$ & \multicolumn{2}{|c|}{1.000} \\
\hline Observations & Instruments & $\begin{array}{c}\text { Number of } \\
\text { groups }\end{array}$ & $\begin{array}{c}\text { Obs. Per } \\
\text { group: } \\
\text { avg. }\end{array}$ \\
\hline 132 & 0.000 & 6 & 22.00 \\
\hline
\end{tabular}

Source: Authors' computation

The study conducted diagnostic statistics to examine the reliability and soundness of the data. The outcome of the AR (1) diagnostic test accepted the null hypothesis of the 1st order, which states that there is no first-order auto serial correlation. The above implies that there exists no link between the current and previous years' error term. In the same way, the AR (2) test proves the non-existence of the 2nd Order Serial correlation between error terms of the current year and two years prior.

The null hypothesis of the Sargan test states that the instruments are exogenous; based on the outcome of the test, the null was rejected. The null hypothesis of the Hansen J test (1982) of overidentifying restriction states that the instruments are valid. Hence the acceptance of the null hypothesis. The article adopted the collapsed with robust and orthogonal options and restricted the number of lags to one.

\subsection{DISCUSSIONS AND TEST OF HYPOTHESIS}

Hypothesis 1: NPLR has a negative affiliation with the bank's profitability as proxied by ROA.

The article developed some hypotheses to test the connection between NPLR and commercial banks' profitability in Ghana. The explored finding of this study indicated that NPLR had a negative and insignificant association with profitability. Nonperforming loans are credit that a bank has granted to customers for interest and the principal to be paid in a specific time. This result is in support of other works of literature. For instance. in India, the findings of Pervez (2019) using a panel regression method, established an adverse connection between NPL and the profitability of banks between the period of 20052018. Again, Suganya and Kengatharan (2018) studied the Specific Factors and Financial Profitability of Domestic Licensed Commercial Banks in Sri Lanka. The study found that NPL was negatively linked to bank profitability. These results on NPLR exhibit a negative relationship with profitability; this article's finding supports such theories.

However, in Nigeria, Sanyaolu (2019) explored deposit money banks' influence from 2008 up to 2017. The results indicated a significant positive association between NPLR and bank profitability calculated proxied as ROA. Similarly, Alshatti (2015) in Jordan study credit risk and commercial banks profitability proxied as ROA. The 13 banks' results show that NPLR had a positive affiliation with the profitability of banks.

\section{Hypothesis 2: Capital adequacy ratio has a positive connection with the bank's profitability.}

Capital adequacy is a central policy's regulatory policy to control the capital required on a commercial in Ghana. The research finds a negative correlation between CAR and ROA of the institutions. Consistent with the findings of Antwi (2019), there exists a negative between CAR (proxied as total equity capital to total assets ratio and bank profitability proxied as return on assets (ROA). Also, Pervez (2019) conducted a study on Capital Adequacy, Risk, and Bank Profitability in India employing the Panel Regression Technique to test the profitability of 65 Banks with different ownership structures in Indian from 2005 -2018. The findings of the study showed that CAR and bank profitability are negatively related. The discovery suggests that commercial banks in Ghana adhere to the regulation set by the Central bank. These findings can be attributed to the 2016 recapitalization policy introduced in the country. The implication is that if banks continue to monitor their capital adequacy ratio, profitability will increase.

Contrary to the above findings, Ozili (2015) examining the elements that affect profitability and Basel capital regulation on Nigerian banks. The studies found a materially positive connection between capital adequacy ratio, return on asset, and net interest margin as proxies for bank profitability. Similarly, Suganya and Kengatharan (2018) conducted a study on the Specific Factors and Financial Profitability of Domestic Licensed Commercial Banks in Sri Lanka. The study found that capital adequacy is positively linked with bank profitability. Again, in Bangladesh, Rahman (2018) explored the nexus of capital regulation, risk, and profitability of banks in Bangladesh; the results exhibited an affirmative association between bank capital and profitability. 


\section{Hypothesis 3. Loan loss provision has a significant positive affiliation with profitability measured by ROA.}

Concurring to the Basel Committee on Banking Supervision (2001) suggests that banks put measures in place to foresee credit and estimate the magnitude of loss provisions to absorb any possible default. The negative implications of loan loss provision affect the profitability of banks. The results showed a negative but insignificant affiliation between LLP and the commercial bank's profitability. The findings are consistent with that of Annor and Obeng (2017), using the listed banks in Ghana from 2007 to 2016. The study employed the random effect regression model and concluded that there is a significant adverse affiliation between LLP and listed banks' profitability. Similarly, in Nigeria, Kolapo
(2012) carried out a study from 2000 to 2010 on C.R. and ROA's impact as a proxy of bank profitability.

Contrary to the above studies, Gizaw (2015) employed the panel data regression technique on Ethiopian banks on the nexus between credit risk and bank performance. The study showed that LLP has a significant and positive correction with ROA. Again, Zulfikar Z. (2019) examined the association between LLP and banks' profitability in Indonesia. Employing the Partial Least Squares-Structural Equation modeling on thirteen banks. The result depicted a positive link between LLP and bank profitability. The results of the findings indicate that banks make a large allocation of their returns into loan loss provision to cover bad debts.

\subsubsection{Summary of the Tests of Hypothesis}

Table 6. Tests of Hypothesis

\begin{tabular}{lcc}
\hline Hypothesis & Analytical Tool & Decision \\
\hline $\mathrm{H}_{1}$ : NPLR has a negative affiliation with bank & Two-Step GMM & Accepted \\
profitability in Ghana. & &
\end{tabular}

\begin{tabular}{lll}
\hline $\mathrm{H}_{2}$ : CAR has a positive affiliation with banks & Two-Step GMM & Accepted \\
profitability in Ghana & & Accepted \\
\hline $\begin{array}{l}\mathrm{H}_{3}: \text { LLP has a positive affiliation with the } \\
\text { profitability of banks in Ghana. }\end{array}$ & Two-Step GMM & \\
\hline Source: Authors' computation &
\end{tabular}

\subsubsection{Robustness Test}

Table 7: Three-Stage Least-Squares Regression

\begin{tabular}{ccccccc}
\hline & Coef & Std. Err & T & Prob. & \multicolumn{2}{c}{ [95\% Conf.Interval } \\
\hline NPLR & -0.003 & 0.013 & -0.27 & 0.790 & -0.029 & 0.022 \\
\hline CAR & 0.014 & 0.008 & 1.72 & 0.086 & -0.002 & 0.031 \\
\hline LLPR & -0.045 & 0.016 & -2.92 & 0.004 & -0.077 & -0.015 \\
\hline SIZE & -0.001 & 0.006 & -2.09 & 0.036 & -0.002 & -0.000 \\
\hline LIQUID & 0.004 & 0.023 & 1.53 & 0.126 & -0.001 & 0.008 \\
\hline INT & 0.000 & 0.000 & 0.83 & 0.404 & -0.000 & 0.000 \\
\hline
\end{tabular}

Source: Authors' computation

The three-stage least-squares estimator was employed to test for the validity of the results. Consistent with the system generalized method of moment outcome, NPLR, LLPR, SIZE all exhibited a negative nexus with ROA with LLPR, SIZE revealing significance at $1 \%$ and $5 \%$, respectively. Furthermore, CAR, LIQUID, and INT showed a positive connection with ROA.

\subsection{CONCLUSION}

This article examined the influence of nonperforming loans, capital adequacy, and loan loss provision on banks' profitability in Ghana. The study period was from 2014 up to 2019 on twenty-three commercial banks. The analysis of the hypothesis developed was through the Two-Step System Generalised Method of Moments estimator. The GMM results uncovered that the non-performing loan ratio, capital adequacy ratio had a negative and insignificant link with the bank's profitability. Again,
CAR exhibited a significantly positive connection with the profitability of banks. On the control variables, the size of the firms indicated a negative and insignificant relationship with profitability. Liquidity, on the other hand, exhibited a direct link with the bank's profitability.

This research makes suggestions for policy and strategic decision making. First, we recommend that banks gather enough information on customers and their businesses to mitigate moral hazard and adverse selection in the process of granting loans to customers. Again, banks should demand a reasonable amount of collateral to safeguard depositors' funds. Lastly, the central bank should continually ensure that banks meet the minimum capital requirements for a sound banking operation.

The study was limited because other dimensions like the impact of mergers, the expertise of the board, and the auditors' independence were not considered. 
Subsequent investigations can include these to explore new insights.

\section{ACKNOWLEDGMENTS}

We sincerely appreciate the contributions of Dr. Ibrahim Muazu (University for Development Studies, Ghana) and Mr. Appiah Michael (PhD. Candidate, Jiangsu University), whose comments and constructive criticism helped to shape this study.

\section{REFERENCES}

1. Abiola, I., \& Olausi, A. S. (2014). The Impact of Credit Risk Management on The Commercial Banks Performance in Nigeria. International Journal of Management and Sustainability, 3(5), 295-306.

2. Alshatti, A. S. (2015). The Effect of Credit Risk Management on Financial Performance of Jordanian Commercial Banks. Investment Management and Financial Innovations, $12(1$ \& 2), 338-345.

3. Annor, E. S., \& Obeng, F. S. (2017). Impact of Credit Risk Management on The Profitability of Selected Commercial Banks Listed on The Ghana Stock Exchange. Journal Of Economics, Management, And Trade, 1-10.

4. https://doi.org/10.9734/JEMT/2017/36881

5. Antwi, F. (2019). Capital Adequacy, Cost Income Ratio, and Performance of Banks in Ghana. International Journal of Academic Research In Business And Social Sciences, 9(10), 168-184.

6. https://doi.org/10.6007/IJARBSS/v9-i10/6471

7. Arellano, M., Bond, S., 1991. Some tests of specification for panel data: Monte Carlo evidence and an application to employment equations. Review of Economic Studies 58 (2), 277-297.

8. Arellano, M., Bover, O., 1995. Another look at the instrumental-variable estimation of errorcomponents models. Journal of Econometrics 68 (1), 29-52.

9. Basel Committee on Banking Supervision (2001). Risk Management Practices and Regulatory Capital: Cross-Sectional Comparison. Available On-Line: Www.Bis.Org.

10. Boahene, S. H., Dasah, J., \& Agyei, S. K. (2012). Credit Risk and Profitability of Selected Banks in Ghana. Research Journal of Finance and Accounting, 3(7), 6-14.

11. Çekrezi, A. (2015). Determinants of Financial Performance of The Insurance Companies: A Case of Albania. International Journal of Economics, Commerce and Management. 3(4), Pp. 1-10.

12. Dietrich, D., \& Hauck, A. (2014). Bank Capital Regulation, Loan Contracts, And Corporate Investment. The Quarterly Review Of Economics And Finance, 54(2), 230-241.

13. https://doi.org/10.1016/j.qref.2013.10.005

14. Edwards, P.\& Turnbull, A. (1994). Finance for Small and Medium Sized Enterprises, Information and The Income Gearing Challenge. International Journal Of Marketing, 12(6), 3-9.

15. https://doi.org/10.1108/02652329410048275
16. Gizaw, M., Kebede, M., \& Selvaraj, S. (2015). The Impact of Credit Risk on Profitability Performance of Commercial Banks in Ethiopia. African Journal Of Business Management, 9(2),

17. https://doi.org/10.5897/AJBM2013.7171

18. Hassen, T., Fakhri, I., Bilel, A., Wassim, T., \& Faouzi, H. (2018). Dynamic Effects of Mergers and Acquisitions on The Performance of Commercial European Banks. Journal Of The Knowledge Economy, 9(3), 1032-1048.

19. https://doi.org/10.1007/s13132-016-0389-1

20. Idowu Abiola \& Awoyemi Samuel Olausi, 2014. "The Impact of Credit Risk Management on The Commercial Banks Performance in Nigeria," International Journal of Management and Sustainability, Conscientia Beam, Vol. 3(5), Pages 295-306.

21. Islam, F. T. (2018). Evaluating Loan Loss Provisioning for Non-Performing Loans and Its Impact on The Profitability of Commercial Banks in Bangladesh. Asian Finance \& Banking Review, 2(2), 33-41.

22. https://doi.org/10.46281/asfbr.v2i2.222

23. Kaaya, I., \& Pastory, D. (2013). Credit Risk and Commercial Banks Performance in Tanzania: A Panel Data Analysis.

24. 16. Kajola, S. O., Adedeji, S. B., Olabisi, J., \& Babatolu, A. T. (2018). Effect of Credit Risk Management on The Financial Performance of Nigerian Listed Banks. International Journal of Business Policy \& Governance, 5(6), 53-62.

25. https://doi.org/10.19085/journal.sijbpg050601

26. Kock, N., \& Lynn, G. (2012). Lateral Collinearity and Misleading Results in Variance-Based Sem: An Illustration and Recommendations. Journal Of The Association For Information Systems, 13(7).

27. https://doi.org/10.17705/1jais.00302

28. Kodithuwakku, S. (2015). Impact of Credit Risk Management on The Performance of Commercial Banks in Sri Lanka.

29. Kolapo, T. F., Ayeni, R. K., \& Oke, M. O. (2012). Credit Risk and Commercial Banks' Performance in Nigeria: A Panel Model Approach. Australian Journal of Business and Management Research, 2(2), 31-38.

30. Krugman, Paul (2009). The Return of Depression Economics and The Crisis Of 2008. W.W. Norton Company Limited. Isbn 978-0-393-07101-6.

31. Kurawa, J.M. And Garba, S. (2014). An Evaluation of The Effect of Credit Risk Management (Crm) On the Profitability of Nigerian Banks, Journal of Modern Accounting and Auditing, 10 (1), Pp. 104-115. Available At:Http://Www.Academia.Edu.

32. Majumder, M. T. H., \& Li, X. (2018). Bank Risk and Performance in An Emerging Market Setting: The Case of Bangladesh. Journal Of Economics, Finance And Administrative Science, 23(46), 199-229.

33. https://doi.org/10.1108/JEFAS-07-2017-0084

34. Merton, R. C. 1974. On the Pricing of Corporate Debt: The Risk Structure of Interest Rates. Journal Of Finance 29:449-470.

35. https://doi.org/10.1111/j.15406261.1974.tb03058.x 
36. Muhammad, I. (2012). Introduction, Reasons and Consequences of Heteroscedasticity.

37. Naceur, S. B., \& Omran, M. (2011). The Effects of Bank Regulations, Competition, And Financial Reforms on Banks' Performance. Emerging Markets Review, 12(1), 1-20.

38. https://doi.org/10.1016/j.ememar.2010.08.002

39. Nasserinia, A., Ariff, M., \& Fan-Fah, C. (2014). Key Determinants of Japanese Commercial Banks Performance. Pertanika Journal of Social Science and Humanities, 22, 17-38.

40. Odunga, R. M., Nyangweso, P. M., Carter, D. A., \& Mwarumba, M. (2013). Credit Risk, Capital Adequacy and Operating Efficiency of Commercial Banks in Kenya. International Journal of Business and Management Invention, 2(9), 6-12.

41. Ogboi, C., \& Unuafe, O. K. (2013). Impact of Credit Risk Management and Capital Adequacy on The Financial Performance of Commercial Banks in Nigeria. Journal of Emerging Issues in Economics, Finance and Banking, 2(3), 703-717.

42. Okoye, V., \& Eze, O. R. (2013). Effect of Bank Lending Rate on The Performance of Nigerian Deposit Money Banks. International Journal of Business and Management Review, 1(1), 34-43.

43. Olugboyega, K. S., Babatunji, A. S., Jayeola, O. L. A. B. I. S.I, \& Tobi, B. A. (2018) Effect of Credit Risk Management on Financial Performance of Nigerian Listed Deposit Money Banks.

44. Ozili, P. K. (2015). Determinants of Bank Profitability and Basel Capital Regulation: Empirical Evidence from Nigeria. Research Journal Of Finance And Accounting, 6(2), 124131.

45. https://doi.org/10.2139/ssrn.2544647

46. Pervez, A., Bansal, R., \& Ugc, P. D. F. (2019). Sub Prime Lending Crises and Performance of Public Sector Bank in India. Pimt, 44.

47. Rahman, M. M., Chowdhury, A. A., \& Mouri, D. E. Y. (2018). Relationship Between Risk-Taking, Capital Regulation and Bank Performance: Empirical Evidence from Bangladesh. Eurasian Journal Of Business And Economics, 11(22), 2957.

48. https://doi.org/10.17015/ejbe.2018.022.02

49. Rahman, M.M., Hamid, K., \& Khan, A. (2015). Determinants of Bank Profitability: Empirical Evidence from Bangladesh. International Journal of Business and Management. 10(8), Pp. 135-150

50. https://doi.org/10.5539/ijbm.v10n8p135

51. Samad, A. (2015). Determinants Bank Profitability: Empirical Evidence from Bangladesh Commercial Banks. International Journal Of Financial Research, 6(3), 173-179.

52. https://doi.org/10.5430/ijfr.v6n3p173

53. Sanyaolu, W. A., Siynbola, T. T., Ogunmefun, G. T., \& Makinde, A. B. (2019). Determinants of Profitability of Nigerian Deposit Money Banks. Economic Review: Journal Of Economics \& Business/Ekonomska Revija: Casopis $\mathrm{Za}$ Ekonomiju I Biznis, 17(1).

54. https://doi.org/10.5937/ekonhor2001031S

55. Shapiro, S. S., \& Wilk, M. B. (1965). An Analysis of Variance Test for Normality (Complete Samples). Biometrika, 52(3/4), 591-611.
56. https://doi.org/10.1093/biomet/52.3-4.591

57. Suganya, S. J., \& Kengatharan, L. (2018). Impact of Bank Internal Factors on Profitability of Commercial Banks in Sri Lanka: A Panel Data Analysis. Journal of Business Studies, 5(1).

58. https://doi.org/10.4038/jbs.v5i1.25

59. Suganya, S. J., \& Kengatharan, L. (2018). Specific Factors and Financial Performance of Domestic Licensed Commercial Banks in Sri Lanka. Scms Journal of Indian Management, 15(2), 5-12.

60. Tariq, W., Usman, M., Mir, H. Z., Aman, I., \& Ali, I. (2014). Determinants of Commercial Banks Profitability: Empirical Evidence from Pakistan. International Journal Of Accounting And Financial Reporting, 4(2), 1-22.

61. https://doi.org/10.5296/ijafr.v4i2.5939

62. Weersainghe, V. E. I. W., \& Perera, T. R. (2013). Determinants of Profitability of Commercial Banks in Sri Lanka. International Journal of Arts and Commerce, 2(10), 141-170.

63. Widarjono, A. (2018). Estimating Profitability of Islamic Banking in Indonesia. Jurnal Keuangan Dan Perbankan, 22(3), 267413.

64. https://doi.org/10.26905/jkdp.v22i3.2197

65. Widyastuti, A., Komara, R., \& Layyinaturrobaniyah, L. (2019). Capital Structure and Bank Performance. Jurnal Bisnis Dan Manajemen, 20(2), 136-144.

66. https://doi.org/10.24198/jbm.v20i2.300

67. Zulfikar, Z \& Wahyuni Sri (2019). The Impact of Discretionary Loan Loss Provision of Sharia Financing on Financial Performance. Banks And Bank Systems, 14(4), 34-41.

68. https://doi.org/10.21511/bbs.14(4).2019.04 